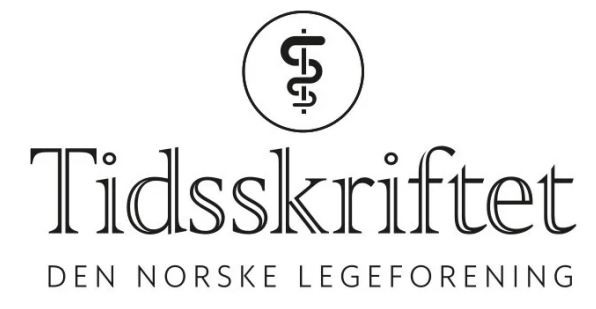

\title{
Brystkreftrisiko ved hormonbehandling hos postmenopausale
}

FRA ANDRE TIDSSKRIFTER

PETTER MORTEN PETTERSEN

Tidsskriftet

Hormonbehandling hos postmenopausale kvinner påvirker risikoen for brystkreft. I en ny studie viser langtidsoppfølging at kombinasjonsbehandling med $\emptyset$ strogen og gestagen gir moderat økt risiko.

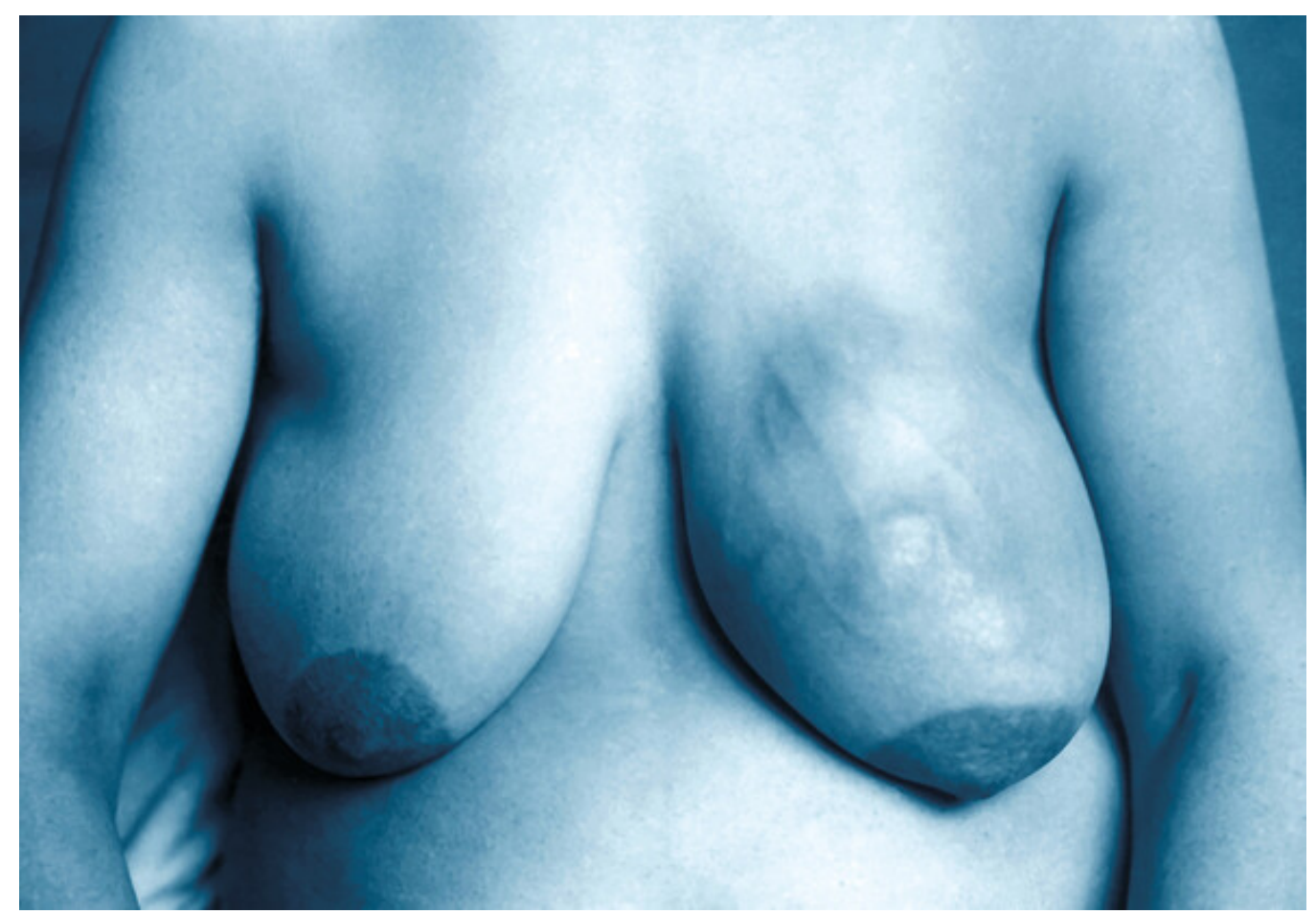

Illustrasjonsfoto: Science Photo Library / NTB Scanpix 
I studien gjennomføres en oppfølging av to tidligere gjennomførte randomiserte, placebokontrollerte studier (1). De nær 30 ooo kvinnene som inngår i materialet, ble rekruttert til studiene i perioden 1993-98 og fulgt ut 2017.

Blant hysterektomerte kvinner ga bruk av østrogen signifikant lavere risiko for brystkreft sammenlignet med placebo, med en årlig insidens på hhv. o,30 \% og o,37\% (hasardratio o,78, $95 \%$ KI o,65-0,93, p = o,005). Konjugert ekvint østrogen (CEE) ga også signifikant redusert risiko for brystkreft som årsak til død, med en årlig insidens på hhv. o,031 \% og o,046 \% (hasardratio o,60, 95\% KI o,37-0,97, p = 0,04).

Hos kvinner med intakt uterus ga kombinasjonsbehandling med konjugert ekvint østrogen og gestagenet medroksyprogesteronacetat signifikant høyere risiko for brystkreft sammenlignet med placebo, med en årlig insidens på hhv. 0,45\% og o,35\% (hasardratio 1,28, $95 \% \mathrm{KI} 1,13-1,45, \mathrm{p}<0,001)$, men det var ingen statistisk signifikant forskjell i brystkreft som årsak til død mellom gruppene.

- Mest overraskende ved denne studien er at den beskyttende effekten av østrogenbehandling fremdeles består. At risikoøkningen ved kombinasjonsbehandling holder seg så konstant og så lenge, var også uventet, sier Giske Ursin, professor II og direktør ved Kreftregisteret.

- Funnene fra disse studiene er ikke nødvendigvis direkte overførbare til Norge, ettersom denne populasjonen er svært selektert, og mange hadde brukt hormoner før start.

- Konjugert ekvint østrogen inneholder mange forskjellige østrogener, med østron som den vesentligste. I Norge brukes som regel østradiol alene, som i registerkoblinger har gitt svak økning av forekomst av små svulster, sier Ursin.

- Ved kombinasjonsbehandling i Norge brukes som regel andre gestagenderivater enn medroksyprogesteronacetat, og noen av kombinasjonspreparatene vi har brukt, har vært forbundet med en sterk økning i brystkreftforekomst, både av små og store svulster, forteller hun.

\section{LITTERATUR}

1. Chlebowski RT, Anderson GL, Aragaki AK et al. Association of menopausal hormon therapy with breast cancer incidence and mortality during long-term follow-up of the women's health initiative randomized clinical trials. JAMA 2020;324:369-80. [PubMed][CrossRef]

Publisert: 8. oktober 2020. Tidsskr Nor Legeforen. DOI: 10.4045/tidsskr.20.0626

(C) Tidsskrift for Den norske legeforening 2023. Lastet ned fra tidsskriftet.no 26. april 2023. 